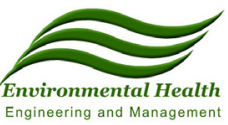

\title{
Assessment of scale formation and corrosion of drinking water supplies in Ilam city (Iran)
}

\author{
${\text { Zabihollah Yousefi }{ }^{1 *} \text {, Farzad Kazemi }}^{2}$, Reza Ali Mohammadpour ${ }^{3}$ \\ ${ }^{1}$ Professor, Department of Environmental Health Engineering, Faculty of Health, Mazandaran University of Medical Sciences, Sari, Iran \\ ${ }^{2} \mathrm{MSc}$, Department of Environmental Health Engineering, Student Research Committee, Faculty of Health, Mazandaran University of \\ Medical Sciences, Sari, Iran \\ ${ }^{3}$ Associate Professor, Department of Biostatistics, Faculty of Health, Mazandaran University of Medical Sciences, Sari, Iran
}

\begin{abstract}
Background: Scaling and corrosion are the two most important indexes in water quality evaluation. Pollutants are released in water due to corrosion of pipelines. The aim of this study is to assess the scale formation and corrosion of drinking water supplies in Ilam city (Iran).

Methods: This research is a descriptive and cross-sectional study which is based on the 20 drinking water sources in Ilam city. Experiments were carried out in accordance with the Water and Wastewater Co. standard methods for water and wastewater experiment. The data were analyzed by using Microsoft Excel and GraphPad Prism 5. The results were compared with national and international standards.

Results: The mean and standard deviation (SD) values of Ryznar, Langelier, Aggressive, Puckorius and Larson-Skold indices in year 2009 were equal to $7.833( \pm 0.28),-0.102( \pm 0.35), 11.88( \pm 0.34), 7.481( \pm 0.22)$ and $0.801( \pm 0.44)$, respectively, and were $7.861( \pm 0.28),-0.175( \pm 0.34), 11.84( \pm 0.37), 7.298( \pm 0.32)$ and $0.633( \pm 0.47)$, for year 2013 respectively. The average of Langelier, Ryznar, Aggression, and Puckorius indices indicate that potable water resources in Ilam city have the tendency to be corrosive. Statistical analysis and figures carried out by GraphPad Prism version 5.04.

Conclusion: The results of different indices for water resources of Ilam city revealed that water supplies of Ilam city were corrosive. Water quality control and replacement of distribution pipes in development of water network should be carried out. Moreover, water pipelines should be preserved with several modes of corrosion inhibition.

Keywords: Corrosion, Scale formation, Water resources, Ilam

Citation: Yousefi Z, Kazemi F, Mohammadpour RA. Assessment of scale formation and corrosion of drinking water supplies in Ilam city (Iran). Environmental Health Engineering and Management Journal 2016; 3(2): 75-80. doi: 10.15171/EHEM.2016.04.
\end{abstract}

\section{Article History:}

Received: 20 February 2016

Accepted: 4 May 2016

ePublished: 18 May 2016

\section{Introduction}

Corrosion is the physical-chemical interaction between the metal and its surroundings which is usually electrochemical in nature and can lead to a change in the metal properties $(1,2)$. The corrosion tends to release the metal pipe particles into the fluids. If the corrosion occurs quickly, it forms a hole and then perforation of pipes which is considered as a path for water contamination in a state of negative suction; but if the water has a tendency to scaling, the diameter of pipe will reduce over the time due to the formation of sediments layers in the inner part of the pipes which ultimately results to the reduction of flow rate (2-4). Unfortunately, there are no precise figures of corrosion and scaling damages in the Iran; nevertheless, the surveys indicate that $30 \%$ of treated water losses is related to decays of pipelines caused by the corrosion which also reduce the shelf life of sanitary equipment $(4,5)$. So far, the corrosion potential of drinking water and its measurement have not been properly evaluated in drinking water distribution networks in cities of Iran. There is little information in this specific context and this issue is neglected even in the approved standards. In addition to financial losses, the release of by-products resulting from the corrosion can easily diminish the willingness of consumers to use water. Moreover, the possibility of releasing heavy metal such as lead, copper, chromium and cadmium can endanger the human health (5-7). Scale formation plays an important role in the formation of gastrointestinal tract (GIT) diseases. The studies show that the by-products of corrosion resulting from inner surface of pipes, can accumulate or deposit in the distribution networks, thereby protecting microorganisms from the effects of disinfectants. These microorganisms can replicate and participate in creating various problems such as undesirable 
taste and odor, biological mass and increasing of corrosion (8-10). There is increase in secondary pollutants in corrosive water, such as increase in the concentration of iron, zinc, copper and manganese which is higher than the given standards in drinking water which lead to taste, odor, color and stains on sanitary services (11). Recently, the parameters including alkalinity, calcium hardness, conductivity, temperature and $\mathrm{pH}$ were analyzed to determine the corrosion or scaling of drinking water and the corrosion or scaling potential as estimated by Langelier and Ryznar indexes; if the corrosive or scaling of water were observed, then the necessary measures should be taken to remove the problem and to achieve the favorable state $(3,11)$. The Langelier saturation index (LSI) is probably the most widely used indicator of scale potential in water supply and drinking water networks. The driving force for scaling potential is in terms of $\mathrm{pH}$, which is a master variable in LSI.

Savari et al compared the methods of corrosion or scaling levels for drinking water distribution network of Ahvaz city. The results of their study revealed that the values of Langelier and Ryznar indexes were -0.56 and 8.34, respectively which show the corrosion state in drinking water of Ahvaz (6). Avazpour et al investigated the corrosive and scaling potentials of drinking water resource in Ilam city and found that the water of that region has corrosive potentials (12). The potential of scaling and corrosion level were also investigated for drinking water in the rural regions of Khash county by Hosseini et al. They observed that the Langelier index (LI) was -0.805 which shows that the drinking water of these regions has corrosive properties (13).

The aim of this study was to determine the corrosion and scaling potential in drinking water of Ilam. Furthermore, appropriate solutions are represented to eliminate this problem based on the present situations.

\section{Methods}

Samples were taken at the standard one-liter (1L) plastic containers and were transferred to a reference laboratory of Water and Wastewater Company. The containers were carefully rinsed before sampling. The storage, transportation and testing of samples were carried out according to standard methods. For each parameters, the qualitative parameters including temperature (by digital thermometer), $\mathrm{pH}$ ( $\mathrm{pH}$ meter, equatic) at the sampling site and other parameters including total dissolved solids (TDS), calcium hardness, alkalinity, chloride, and sulfate in the laboratory were measured according to the instructions contained in the standard method. All experiments were conducted 3 times. In this research, five main indexes including LSI, Ryznar stability index (RSI), Larson-Skold (LS), Puckorius Scaling Index (PSI) and Aggressive Index (AI) were applied to evaluate the corrosion and scaling potential of drinking water system in Ilam city, western Iran. Initially, the $\mathrm{pH}$ 's ( $\mathrm{pH}$ at saturated state of calcium carbonate) was calculated by equation 1 using the available parameters including $\mathrm{pH}$, temperature, TDS, calcium hardness and alkalinity. Statistical analysis and figures were carried out by GraphPad Prism version 5.04. The indices were calculated based on the following formulas (14-20):

1. LSI was calculated using equation $1(18,19)$.

$\mathrm{LSI}=\mathrm{pH}-\mathrm{pHs}$

$\mathrm{pHs}=(9.3+\mathrm{A}+\mathrm{B})-(\mathrm{C}+\mathrm{D})$

$\mathrm{A}=\left(\log _{10}(\mathrm{TDS})-1\right) \cdot 10$

$\mathrm{B}=-13.12 \times \log _{10}\left({ }^{\circ} \mathrm{C}+273\right)+34.55 \quad$ Temperature $\left({ }^{\circ} \mathrm{C}\right)$ $\mathrm{C}=\log _{10}\left(\mathrm{Ca}_{2}+\mathrm{CaCO}_{3}\right)-0.4 \quad$ Calcium hardness (mg.1 $\left.\mathrm{CaCO}_{3}\right)$,

$\mathrm{D}=\log _{10}$ (Alkalinity as $\mathrm{CaCO}_{3}$ ) Alkalinity, mg.1 $\mathrm{CaCO}_{3}$ 2. RSI was calculated using equation 3 .

$\mathrm{RI}=2 \mathrm{pHs}-\mathrm{pH}$

Interpretation of the results obtained from Langelier and Ryznar indexes is presented in Table 1.

Table 1. Indexes criteria with the interpretation of the water status

\begin{tabular}{|c|c|c|}
\hline Type of Index & Index Criteria & Interpretation \\
\hline \multirow{3}{*}{ Langlier } & $\begin{array}{l}\mathrm{LI}>0 \text { The water is supersaturated and has tendency to } \\
\text { scaling }\end{array}$ & The water is supersaturated and has a tendency to scaling. \\
\hline & $\mathrm{LI}=0$ The water is saturated and has not tendency to scaling & The water is saturated and has no tendency to scaling. \\
\hline & $\mathrm{LI}<0$ Water is not saturated and has tendency to corrosion & Water is not saturated and has a tendency to corrosion \\
\hline \multirow{5}{*}{ Ryznar } & $\mathrm{RSI}<5.5$ water is scaling rigorously & Water is scaling rigorously \\
\hline & $5.5<\mathrm{RSI}<6.2$ water is scaling & Water is scaling \\
\hline & $\begin{array}{l}6.2<\mathrm{RSI}<6.8 \text { water is neutral - balanced (has not corrosive } \\
\text { or scaling properties) }\end{array}$ & Water is neutral - balanced (has no corrosive or scaling) properties) \\
\hline & $6.8<\mathrm{RSI}<8.5$ Water is corrosive & Water is corrosive \\
\hline & RSI > 8.5 water is corrosive rigorously & Water is rigorously corrosive \\
\hline \multirow{3}{*}{ Larson-Skold } & LS $<0.8$ Water has tendency to scaling & Water has a tendency to scaling. \\
\hline & $0.8<\mathrm{LS}<1.2$ corrosion rates may be higher than expected & Corrosion rates may be higher than expected \\
\hline & LS > 1.2 water is the high rates localized corrosive & Water shows a high rate of localized corrosives. \\
\hline \multirow[t]{2}{*}{ Puckorius } & $\begin{array}{l}\text { PSI }<6.1 \text { scaling is unlikely to occur (water has tendency to } \\
\text { scaling) }\end{array}$ & Scaling is unlikely to occur (water has tendency to scaling) \\
\hline & PSI > 7 likely to dissolve scale (water is corrosive) & likely to dissolve scale (water is corrosive) \\
\hline \multirow{3}{*}{ Aggressive } & Al > 12 Water has scaling property (non-aggressive) & Water has scaling property (non aggressive) \\
\hline & $\begin{array}{l}10<\mathrm{Al}<12 \text { water is approximately corrosive (moderately } \\
\text { aggressive) }\end{array}$ & Water is approximately corrosive (moderately aggressive) \\
\hline & $\mathrm{Al}<10$ water is severely corrosive (very aggressive) & Water is severely corrosive (very aggressive) \\
\hline
\end{tabular}


Where $\mathrm{pH}$ is the actual $\mathrm{pH}$; $\mathrm{pH}$ 's is the $\mathrm{pH}$ of water at saturated state of calcium carbonate; LI and RI are Langelier and Ryznar indexes, respectively.

3. LS index was calculated using equation 4.

$\mathrm{LS}=\left(\mathrm{C}\left(\mathrm{Cl}^{-}\right)+\mathrm{C}\left(\mathrm{SO}_{4}^{2+}\right)\right) \cdot\left(\mathrm{C}\left(\mathrm{HCO}^{3-}\right)+\mathrm{C}\left(\mathrm{CO}_{3}^{2-}\right)\right)$

Where $\mathrm{C}\left(\mathrm{Cl}^{-}\right)$is the chloride concentration; $\mathrm{C}\left(\mathrm{SO}_{4}{ }^{2+}\right)$ is the sulfate concentration (mg.l); $\mathrm{C}\left(\mathrm{HCO}^{-}\right)$is the concentration of bicarbonate and $\mathrm{C}\left(\mathrm{CO}_{3}{ }^{2-}\right)$ is the carbonate concentrations (mg.l $\mathrm{CaCO}_{3}$ ). When LS is lower than 0.8 , chloride and sulfate are unlikely to interfere with the formation of protecting film or water has tendency to scaling. When the water and LS values are higher than 1.2, a high rates of localized corrosion may be expected. If LS values fall between 0.8 and 1.2, corrosion rates may be higher than expected.

4. PSI was calculated by equations of 5 and 6 .

$\mathrm{PI}=2 \mathrm{pHs}-\mathrm{pHeq}$

$\mathrm{pH}_{(\mathrm{aq})}=1.465 \log (\mathrm{T}-\mathrm{ALK})+4.54$

Where Heq, T-ALK and PI are the $\mathrm{pH}$ of water at equilibrium, total alkalinity $\left(\mathrm{mg} .1 \mathrm{CaCO}_{3}\right)$ and PSI, respectively. If this index for water is higher than 7 (PI>7), water is corrosive. The scaling properties can be seen at $\mathrm{PI}<6(18,20)$. PSI is only index that uses the driving force for calcium carbonate scale formation (19).

5. AI was applied in equation 7 to evaluate the corrosive potentials.

$\mathrm{AI}=\mathrm{pH}+\mathrm{Log}(\mathrm{T}-\mathrm{Alk} . \times \mathrm{H})$

In the above equation, T-Alk is the total alkalinity (mg.l $\mathrm{CaCO}_{3}$ ) and $\mathrm{H}$ is the calcium hardness (mg.l CaCO 3 ).Values less than 10 and between 10-12 of AI indicate that the water is severely corrosive and approximately corrosive respectively. However, the values higher than 12 show the scaling properties of water $(8,12)$. AI is a suitable index for Asbestosis-cement pipelines (19). Index criteria with their interpretation of the water status are shown in Table 1.

Results

The values of various indexes of corrosion and scaling level of drinking waters in Ilam city are represented in Figures 1 to 5 between the year 2009 and 2013 .

As shown in Figure 1, the lowest and highest value of LI (2009) were observed at well No. $2(-0.8)$ and well No. 12 (0.335), respectively which shows relatively high corrosive properties at well No. 2.

In Figure 1, the maximum value for the LI (2013) was determined to be 0.4 for the well No.1 and minimum value was related to well No. 13 and was equal to -0.65 .

Figure 2 shows the values of the Ryznar index (2009 \& 2013) in drinking water sources in Ilam. The results revealed that the maximum and minimum values of AI were equal to 8.42 in well No. 2 and 7.3 for well No. 12, respectively in 2009. Also these items were 8.3 in well No. 17 and 7.3 in Well No. 1, respectively in 2013.

Figure 3 shows the values of the AI (2009), in drinking water sources in Ilam. The calculated results showed that the maximum and minimum values of $\mathrm{AI}$ were equal to 12.27 in well No. 11 and 11.26 for well No. 2, respectively in 2009. Moreover, these items were 12.4 in well No. 19

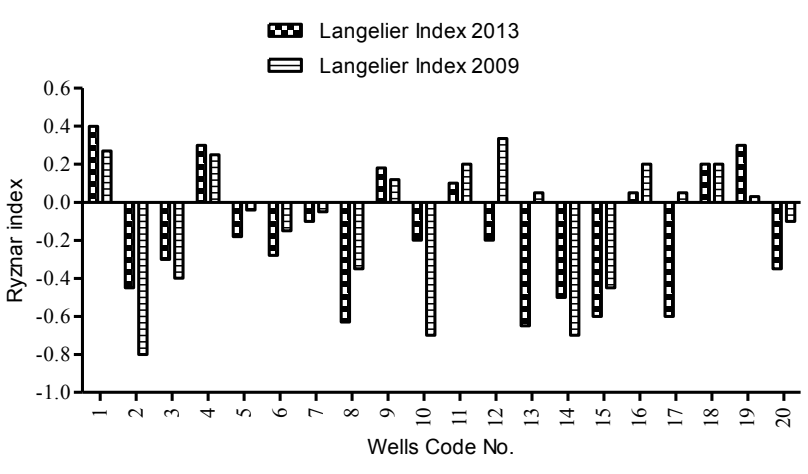

Figure 1. The value of the $\mathrm{LI}$ of drinking water sources of llam in year 2009.

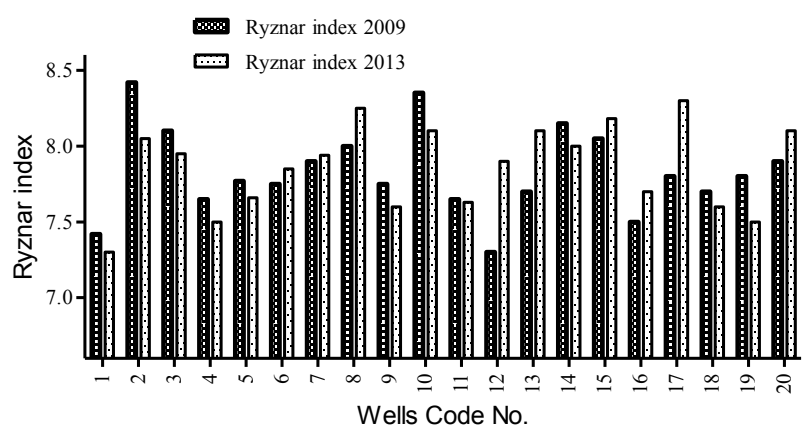

Figure 2. The value of the Ryznar index of drinking water sources of llam in year 2009 .

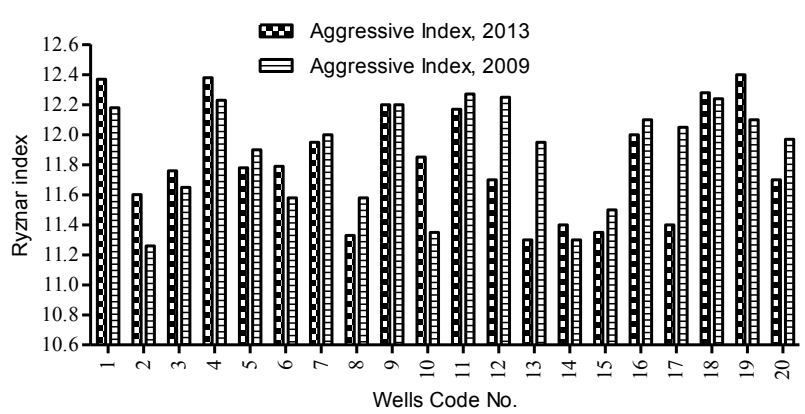

Figure 3. The value of the Al of drinking water sources of llam in year 2009.

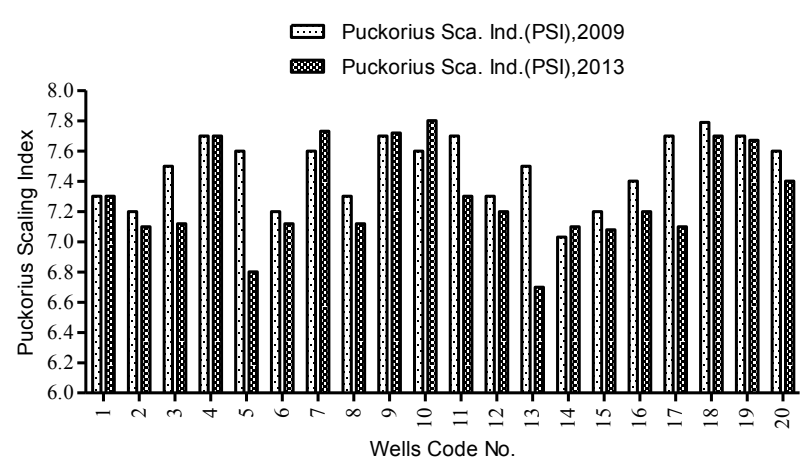

Figure 4. The value of the PSI of drinking water sources of Ilam in year 2009 . 
and 11.30 in Well No. 13, respectively in 2013.

Result of PSI of the data in Figure 4 shows that the highest level PSI of Well No. 18 was obtained as 7.79 and the lowest for wells No. 14 was 7.03 in 2009. Moreover, the same items were 7.8 in well No. 10 and 6.7 in Well No. 13, respectively in 2013 .

Figure 5 based on the values of the LS index shows the drinking water sources in Ilam in 2009 and 2013. As shown in the figure, the highest level LS index of well No. 17 was obtained as 1.36 and the lowest for well No. 5 was 0.14 in 2009. Moreover, the same items were 1.38 in well No. 19 and 0.138 in well No. 12, respectively in 2013 .

Descriptive statistical analysis for all indexes applied in this study is displayed in Table 2. As shown in Table 2, most indexes show that the water of Ilam has the tendency to corrosion.

The mean and standard deviation(SD) values of Ryznar, Langelier, Aggressive, Puckorius and Larson-Skold indices in year 2009 were equal to $7.833( \pm 0.28),-0.102( \pm 0.35)$, $11.88( \pm 0.34), 7.481( \pm 0.22)$ and $0.801( \pm 0.44)$, respectively. By survey of corrosion indices, it was found that Ilam drinking water resource in year 2009 was corrosive.

The mean and SD values of Ryznar, Langelier, Aggressive, Puckorius and Larson-Skold indices in year 2013 were equal to $7.861( \pm 0.28),-0.175( \pm 0.34), 11.84( \pm 0.37)$, $7.298( \pm 0.32)$ and $0.633( \pm 0.47)$, respectively. By survey of corrosion indices, it was found that Ilam drinking water resource in year 2013 was corrosive (the same as 2009).

\section{Discussion}

Corrosion and scaling should be carefully considered in the monitoring of water distribution systems, because the neglect of attention to the chemical quality of water and the emergence of any of the above phenomena can cause damage to the health and economy. The water of 13 from 20 studied wells are corrosive according to the obtained values of LI. Moreover, the values of Ryznar index indicate that there is no well with scaling water properties. In a study carried out by Aiman et al (14) to evaluate the water

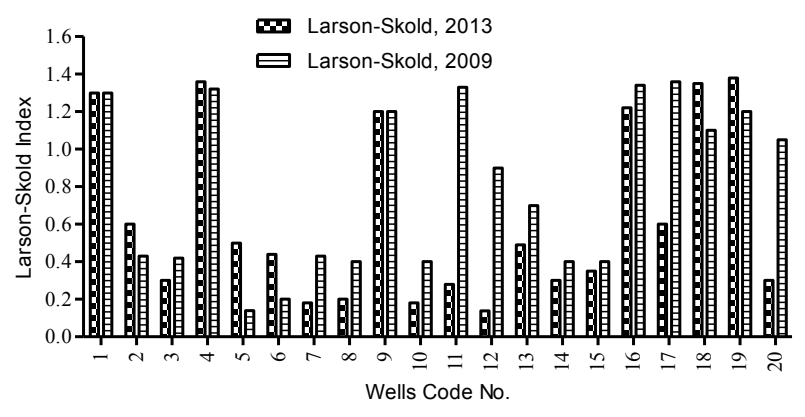

Figure 5. The value of the LSI of drinking water sources of Ilam in year 2009 .

quality and the corrosion and scaling potential of Tafila in southern Jordan using LSI and RSI indexes, the results indicated that LSI values were negative and in the range of -0.39 to -1.5 and RSI values were about 7.8 to 9.8 and it indicates that the water is corrosive. Heating and evaporation of water along with the release of $\mathrm{CO}_{2}$ have been attributed as reasons for this event (14). The chemical water quality monitoring its balance control can lead to an increase in the useful life of water supply facilities and the reduction of possible leakage and water losses. These requirements are very essential in countries such as Iran. Savari et al also carried out a study to compare the methods of corrosion or scaling levels for drinking water distribution network of Ahvaz city. The results of their study reveals that the values of Langelier and Ryznar indexes were -0.56 and 8.34 , respectively, which demonstrates that the drinking water of Ahvaz city is in a corrosive state (6). In recent works, most water resources in Ilam city have corrosive properties based on LI; with respect to values of Ryznar index, the scaling can be observed in networks using the water from wells. Although scaling or corrosion potential in the country's water balance are not considered in water quality monitoring systems, nevertheless, some studies reveal that the water resources in some of the provinces of Iran has no suitable chemical balance and the corrosion and scaling phenomena can be observed which is

Table 2. Descriptive statistical analysis for all indexes applied in this study

\begin{tabular}{|c|c|c|c|c|c|c|c|c|c|c|}
\hline & RI, 2013 & RI, 2009 & LI, 2013 & ㄴI, 2009 & Al, 2013 & Al, 2009 & PSI, 2013 & PSI, 2009 & LSI, 2013 & LSI, 2009 \\
\hline Number of values & 20 & 20 & 20 & 20 & 20 & 20 & 20 & 20 & 20 & 20 \\
\hline Minimum & 7.300 & 7.300 & -0.650 & -0.800 & 11.30 & 11.26 & 6.700 & 7.030 & 0.138 & 0.140 \\
\hline 25\% Percentile & 7.608 & 7.663 & -0.487 & -0.387 & 11.45 & 11.58 & 7.100 & 7.300 & 0.285 & 0.400 \\
\hline Median & 7.920 & 7.785 & -0.200 & -0.005 & 11.79 & 11.99 & 7.200 & 7.550 & 0.465 & 0.800 \\
\hline 75\% Percentile & 8.100 & 8.038 & 0.1600 & 0.200 & 12.19 & 12.20 & 7.693 & 7.700 & 1.215 & 1.275 \\
\hline Maximum & 8.300 & 8.420 & 0.4000 & 0.335 & 12.40 & 12.27 & 7.800 & 7.790 & 1.380 & 1.360 \\
\hline $10 \%$ Percentile & 7.500 & 7.428 & -0.627 & -0.700 & 11.33 & 11.31 & 6.828 & 7.200 & 0.180 & 0.220 \\
\hline 90\% Percentile & 8.243 & 8.330 & 0.300 & 0.268 & 12.38 & 12.25 & 7.729 & 7.700 & 1.359 & 1.339 \\
\hline Mean & 7.861 & 7.833 & -0.175 & -0.102 & 11.84 & 11.88 & 7.298 & 7.481 & 0.633 & 0.801 \\
\hline Std. Deviation & 0.282 & 0.286 & 0.341 & 0.349 & 0.373 & 0.345 & 0.322 & 0.222 & 0.468 & 0.444 \\
\hline Std. Error & 0.063 & 0.064 & 0.076 & 0.0782 & 0.083 & 0.077 & 0.072 & 0.0496 & 0.1047 & 0.099 \\
\hline Lower $95 \% \mathrm{Cl}$ of mean & 7.728 & 7.699 & -0.335 & -0.265 & 11.66 & 11.72 & 7.147 & 7.377 & 0.4142 & 0.593 \\
\hline Upper $95 \% \mathrm{Cl}$ of mean & 7.993 & 7.967 & -0.0157 & 0.0618 & 12.01 & 12.04 & 7.449 & 7.585 & 0.853 & 1.009 \\
\hline Coefficient of variation & $3.60 \%$ & $3.65 \%$ & $194.51 \%$ & $343.61 \%$ & $3.15 \%$ & $2.91 \%$ & $4.42 \%$ & $2.97 \%$ & $73.96 \%$ & $55.48 \%$ \\
\hline Geometric mean & 7.856 & 7.828 & & & 11.83 & 11.88 & 7.291 & 7.478 & 0.481 & 0.659 \\
\hline Lower $95 \% \mathrm{Cl}$ of geo. mean & 7.724 & 7.696 & & & 11.66 & 11.72 & 7.142 & 7.374 & 0.335 & 0.476 \\
\hline Upper $95 \% \mathrm{Cl}$ of geo. mean & 7.990 & 7.963 & & & 12.01 & 12.04 & 7.443 & 7.583 & 0.691 & 0.913 \\
\hline
\end{tabular}


relatively consistent with the results of this study $(15,16)$. Dehghani et al (17) also carried out a study in Fars province and they observed that the values of Langelier and Ryznar indexes of drinking water of Shiraz city were 0.42 and 6.7, respectively. They also reported that $95 \%$ of the tested samples had scaling properties based on LI. Furthermore, they implied that $82 \%$ and $12 \%$ of samples were in balanced and corrosive situation (17). Mokhtari et al (11) also investigated the scaling potentials and corrosion of drinking water networks system of Ardabil and they observed the corrosive tendency in the water of this city. They suggested that the monitoring of related parameters should be carried out and the corrosion-resistant pipes and material be utilized in the drinking water networks (11). The AI is a scale of water tendency to destroy the water transmission pipes which is made of asbestos cement. This index can be utilized for water pipes made of asbestos cement at temperatures between $4^{\circ} \mathrm{C}$ and $27^{\circ} \mathrm{C}$ $\left(40\right.$ to $\left.80^{\circ} \mathrm{F}\right)$. The values less than 10 is related to severely corrosive properties of water and the values between 10-12 indicate that the water is approximately corrosive, nevertheless, the values higher than 12 show the scaling properties of water. The results of this study show the high corrosion of the drinking water of Ilam based on the AI. Generally, the methods utilized to calculate the level of corrosion and scaling of water were not considered as two important parameters. These two parameters are the water buffering capacity (buffer capacity) and the maximum deposition of natural water in equilibrium (maximum amount of deposit). In PSI, the possibility of investigating the relationship between supersaturated situation of water and scaling with respect to these two parameters is provided. In this index, the $\mathrm{pH}_{\mathrm{msr}}$ was applied instead of $\mathrm{pH}_{\mathrm{ep}}$ that represents the equilibrium activity of hydrogen ions. If the value is less than 6.1, the water tends to scaling and if it was more than or equal to 6.1, the water does not tend to scaling. The water resources in Ilam city have higher values than the determined amount. A study was carried out on drinking water in Bandar Abbas by Qezavati et al and it revealed that the average of this index during the sampling period was measured as 9.04 which is in line with our study (9). The results of the study of Aghapour and Boini shows that the output water of the water treatment plant No. 1 of Urmia is corrosive according to Ryznar and Puckorius scaling indexes but the LI was not significant due to the water velocity and the $\mathrm{pH}>8$ (18). LSI was provided to determine the corrosive properties of water on steel pipes, steel tubes with light carbon structure (low-carbon steel) and cast iron pipes. All of the examined samples of waters have values less than this amount. Ahmadpour et al (15) evaluated the corrosion and scaling indexes of the Manujan city and observed that the water has scaling potential based on LI but it was corrosive according to RSI and PSI. Moreover, there was no corrosive potential based on AI (15).

\section{Conclusion}

According to mean values of LSI, RSI, PSI and AI indexes in both sampling times (2009 and 2013), water obtained from Ilam water resources has the tendency to be corrosive. Due to the relative corrosion in the drinking water network systems, it is suggested that methods such as; cathodic protection, color coatings and polished, cement coating, the use of sodium silicate in concentrations of 16$12 \mathrm{mg} .1$, the use of salt, phosphates and chromates covers, the metal oxide coating on the metal, galvanized coating, coated with molten zinc, tin coatings (in highly corrosive environments such as acids and salts, has great stability), coatings cadmium and stainless steel be utilized to protect and control the network.

Other suggestions for prevention of scaling and corrosion are as follows:

- There is need to have $\mathrm{pH}$ adjustment of water and providing the proper $\mathrm{pH}$.

- Prevention of petrol, petroleum and sulfur compounds discharged around the surroundings and path of water transmission and distribution need to be controlled.

- Prevention of construction waste discharge containing lime around wells and other path of water transmission and distribution have to be anticipated.

- Isolation of the pipelines in direction with the high groundwater level and use of sand in the piping for the passage of water is preferred.

- The use of polyethylene pipes is recommended where the network development is considered.

\section{Acknowledgements}

This study is indebted to the Sari Public Health School and Vice Chancellor for Research and Technology in Mazandaran University of Medical Sciences, who have provided support for this project. Water and Wastewater Company in Ilam province whom have shown good cooperation and collaboration as well as Ilam School of Public Health in the experiment verification of the samples. It should be noted that this article was extracted from the Master's thesis of F. Kazemi (research project code 1268 in Mazandaran University of Medical Sciences).

\section{Ethical issues}

There were no ethical issues for writing of this article.

\section{Competing interests}

The authors declare that they have no conflict of interests.

\section{Authors' contributions}

All authors were involved in all stages of the article. On behalf of the co-authors, the corresponding author bears full responsibility for this submission.

\section{References}

1. Pirialam R, Shams G, Shahmansoori M, Farzadkia M. Determination of corrosion and sedimentation potential in drinking water distribution system of Khorramabad city by corrosion indices and weight loss method. Lorestan Univesity of Medical Sciences Journal 2008; 10(3): 79-86. [In Persian]. 
2. Karegar M, Rahaimzadeh H, Sadeghi M, Dadban Y. Corrosion and scaling ability of drinking water distribution network in Gorgan and its influencing factors. Second National Conference on Water and Wastewater Pperation approach; Tehran, Iran; 2008. [In Persian].

3. NikPour B, Yousefi Z, Mortazavi M, Noshadi M. Evaluation of corrosion and sedimentation potential of water distribution network in Behshahr city. 9th National Conference on Environmental Health; Esfahan, Iran; 2006. [In Persian].

4. Mazlomi S, Haybati B, Fazlzadeh M, Derakhshan S. Evaluation of corrosion and sedimentation potential of drinking water in Mianeh city 2008. 12th National Conference on Environmental Health; Shahid Beheshti University of Medical Science, Iran; 2009. [In Persian].

5. Ghaneian MT, Ehrampoush MH, Ghanizadeh G, Amrollahi M. Survey of corrosion and precipitation potential in dual water distribution system in kharanagh district of yazd province. Journal of Toloo-E-Behdasht 2009; 7(3-4): 65-72. [In Persian].

6. Savari J, Jafarzadeh N, Hasani AH, Shams G. Comparison of survey methods of corrosion in distribution system of drinking water in Ahwaz. 10th National Conference on Environmental Health; Hamedan, Iran; 2007. [In Persian].

7. Babaie A, Mazloomi S, Rabie A, Abouee E, fazlzadeh $\mathrm{M}$, nouroozie M. Corrosion and Scaling Potential of Shiraz drinking water. 12th National Conference on Environmental Health; Shahid Beheshti University of Medical Science, Iran; 2009. [In Persian].

8. Nasehinia H, Naghizadeh A, Ravankhah M. Determining of corrosion or sedimentation of drinking water in Dameghan city with corrision indexes. 4th Conference \& Exhibition of Environmental Engineering; Tehran, Iran; 2010. [In Persian]

9. Qezavati M, Noshadi M, Marandi R. Evaluation of Chemical quality and corrosion potential of drinking water produced at the Bandar Abbas refinery And the entrance to it. 12th National Conference on Environmental Health; Shahid Beheshti University of Medical Science, Iran; 2009. [In Persian].

10. Mazlomi S. Evaluation of corrosion and sedimentation potential of drinking water in Shiraz city. Journal of Tolooe-behdasht 2008; 7(1,2): 64-72. [In Persian].
11. Mokhtari S, Aaliqadri M, Hazrati S, Sadeghi H, Gharari N, Ghorbani L. Evaluation of corrosion and precipitation potential in Ardebil drinking water distribution system by using langelier \& ryznar indexes. Res Sci J Ardabil Univ Med Sci 2010; 1(1): 14-23. [In Persian].

12. Avazpour M, Gholami M, Ali R. Evaluation of corrosion and sedimentation potential of drinking water in Ilam city. 11th National Conference on Environmental Health; Zahedan, Iran; 2008. [In Persian].

13. Husseini A, Bazrafshan A, Nori M, Mirpour AA. Evaluation of the corrosivity of drinking water in villages of Khash city in 2007. 11th National Conference on Environmental Health; Zahedan, Iran; 2008. [In Persian].

14. Aiman E, Al-Rawajfeh, Ehab M, Al-Shamaileh. Assessment of tap water resources quality and its potential of scale formation and corrosivity in Tafila Province, South Jordan. Desalination 2007; 206(1-3): 322-32.

15. Ahmadpour A, Zazooli M, Ghaneian M. The survey on potential of corrosion and sedimentation in drinking water distribution network of Manujan city and its effective factor. 14 National Conference on Environmental Health; Yazd, Iran; 2011. [In Persian].

16. Mahvi A, Dindarlou K, Jamali A, Alipour V. Corrosion and scaling in Bandar Abbas Pipe water network. Hormozgan Medical Journal 2011; 14(4): 335-340. [In Persian].

17. Dehghani M, Tex F, Tabatabaei HR. The survey on sedimentation and corrosion condition of drinking water in water supply and distribution network of Shiraz city. 11th National Conference Of Environmental Health; Zahedan, Iran; 2008. [In Persian].

18. Aghapour AA, Boini AM. The survey on corrosion and sedimentation output of the plant no.1 of urumieh water treatment in 2008. 12th National Conference of Environmental Health; Shahid Beheshti University of Medical Science, Iran; 2009. [In Persian].

19. Taghipour H, Shakerkhatibi M, Pourakbar M, Belvasi M. Corrosion and scaling potential in drinking water distribution system of Tabriz, Northwestern Iran. Health Promot Perspect 2012; 2(1): 103-111.

20. Shams M, Mohamadi A, Sajadi SA. Evaluation of corrosion and scaling potential of water in rural water supply distribution networks of Tabas, Iran. World Applied Sciences Journal 2012; 17(11): 1484-9. 